\title{
Effect of Various Sources of Nutrients on Oats Fodder
}

\author{
Alankar Singh $^{1 *}$ and Pallavi \\ ${ }^{1}$ K.V.K. Ranichauri, UUHF, Bharsar, India \\ ${ }^{2}$ Department of Agriculture, Dolphin (PG) Institute of Biomedical \& Natural Sciences, \\ Dehradun, India \\ *Corresponding author
}

Keywords

Oat fodder,

Vermicompost and

Protein content

Article Info

Accepted:

10 January 2019

Available Online:

10 February 2019

\section{A B S T R A C T}

The field experiment was laid out in factorial randomized block design with three replications. The treatments comprised of three varieties of oat (Kent, JHO 822, JHO 851) as the main plot treatments and nine integrated nutrient management viz., $50 \%$ of Recommended dose of Fertilizer (RDF) $\left(\mathrm{F}_{1}\right), 75 \%$ of RDF $\left(\mathrm{F}_{2}\right), 100 \%$ of RDF $\left(\mathrm{F}_{3}\right), 50$ $\%$ of RDF + Vermi Compost $\left(\mathrm{F}_{4}\right), 50 \%$ of RDF + Azotobactor $\left(\mathrm{F}_{5}\right), 50 \%$ of RDF + Vermi Compost + Azotobactor $\left(\mathrm{F}_{6}\right), 75 \%$ of RDF + Vermi Compost $\left(\mathrm{F}_{7}\right), 75 \%$ of RDF + Azotobactor $\left(\mathrm{F}_{8}\right)$ and $75 \%$ of $\mathrm{RDF}+$ VermiCompost + Azotobactor $\left(\mathrm{F}_{9}\right)$ as the sub plot treatments. The growth parameters of oat crop like plant height, leaf area index and dry matter accumulation plant ${ }^{-1}$ were in general increased in all the treatments with the successive growth stages. The integrated nutrient management with application of proved most beneficial in enhancing all these growth parameters of oat crops. Green fodder and dry matter production were increased significantly up to (456.33 and $\left.466.78 \mathrm{q} \mathrm{ha}^{-1}\right)$ and (97.01 and $98.79 \mathrm{q} \mathrm{ha}^{-1}$ ) respectively, with the application of $75 \%$ of RDF + Vermi Compost + Azotobactor during both the years. The quality of fodder with respect to integrated nutrient management in plant in terms of protein content improved significantly due to application of $75 \%$ of RDF + Vermi Compost + Azotobactor during both the years.

\section{Introduction}

Oats has gained some popularity among farmers as a winter forage crop. Oats (Avena sativa L.), locally known as javi, jai, or jodar, belong to the poaceae family. Oats is a crop of Mediterranean origin; not as old as wheat and barley, but their domestication dates back to ancient times. Oats is one of the most important cereal fodder crops grown in winter season requires a greater attention on a part of grower to improve the fodder production and its quality. A well- distributed rainfall of 400 $\mathrm{mm}$ and an optimum temperature range 16$32^{\circ} \mathrm{C}$ during the four months duration is sufficient to meet its requirement as a fodder crop. It is a quick growing, palatable, succulent and nutritious crop and forms an excellent combination when fed along with other cold season legumes, like berseem or Egyptain clover (Trifolium alexandrinum), Lucerne or alfalfa (Medicago sativa), Indian clover (Melilotus indica), Persian clover (Trifolium resupinatum) and pea (Pisum 
arvense), or vetch (Vicia sativa) (Thomson et $a l ., 1990)$. The oats can provide green fodder after 60-70 days in emergency to tide over the scarcity period but after 90-100 days to get large quantity of fodder. Due to excellent growth habit, quick regrowth after first cut and better nutritive value, it has acquired wider adoption in northern, central and north west regions of the country. Green fodder contains $10-12 \%$ protein and $30-35 \%$ dry matter. The oat crop is generally grown in marginal land with minimum fertilizer and thus the production is very low (Oad et al, 2014).The integration of organic sources and synthetic sources of nutrients not only supply essential nutrients but also have some positive interaction to increase nutrient use efficiency and thereby reduce environmental hazards. Addition of organic manures to cultivated land helps recycle nutrients and reduce fertilizer costs in crop production systems. Moreover, the soil nutrient availability derived from organic manure application is not well known. In addition, application of organic manure or others organic wastes may also generate a positive residual effect that should be taken into account when planning the next crop (Eghball et al., 2014; Hirzel et al., 2017).

\section{Materials and Methods}

The experiment was conducted in Agricultural Research Farm of Amar Singh (PG) College, Lakhaoti, Bulandshar (U.P.) during 2009-10 and 2010-11 on a well drained sandy loam soil. The experiment was carried out at the same site and lay out during both the years. The experimental site is situated at a latitude of $28.4^{\circ}$ North and longitude of $77.1^{\circ}$ East with an altitude of 207.1 metre above the mean sea level. Generally, temperature is maximum during May-June and lowest in December-January. The experiment was laid out in factorial randomized block design with three replications at the same site during both the years.
A. Varieties-
i. $\quad$ Kent $\left(\mathrm{V}_{1}\right)$
ii. $\quad \mathrm{JHO}-822\left(\mathrm{~V}_{2}\right)$
iii. $\mathrm{JHO}-851\left(\mathrm{~V}_{3}\right)$

B. Fertilizer Management:

i. $50 \%$ of Recommended dose of Fertilizer (RDF) $\left(\mathrm{F}_{1}\right)$

ii. $\quad 75 \%$ of $\operatorname{RDF}\left(\mathrm{F}_{2}\right)$

iii. $\quad 100 \%$ of $\mathrm{RDF}\left(\mathrm{F}_{3}\right)$

iv. $\quad 50 \%$ of RDF + Vermi Compost $\left(\mathrm{F}_{4}\right)$

v. $\quad 50 \%$ of RDF + Azotobactor $\left(\mathrm{F}_{5}\right)$

vi. $50 \%$ of RDF + Vermi Compost + Azotobactor $\left(\mathrm{F}_{6}\right)$

vii. $\quad 75 \%$ of $\mathrm{RDF}+$ Vermi Compost $\left(\mathrm{F}_{7}\right)$

viii. $\quad 75 \%$ of $\mathrm{RDF}+$ Azotobactor $\left(\mathrm{F}_{8}\right)$

ix. $\quad 75 \%$ of RDF + VermiCompost + Azotobactor $\left(\mathrm{F}_{9}\right)$

Parameters considers were plant height, leaf area index, dry mattter accumulation/ plant and protein content.

\section{Results and Discussion}

The integrated nutrient management with 75 $\%$ of RDF + Vermi Compost + Azotobactor proved most beneficial in enhancing all the growth parameters of fodder oat crop significantly along with variety JHO 822 at most of the stages during both the years. The higher plant height and more number of green leaves in vermicompost + Azotobactor may be due to the fact that in vermicompost mineralization is rapid. A large portion of nitrogen in vermicompost is in organic fractions, but 20 to 40 per cent of the total nitrogen is inorganic (Willrich et al., 1974). Whereas, vermicompost also increases the population of beneficial microorganisms such as $\mathrm{N}$-fixers, P-solubilizers and increases the nitrogenase and urease enzyme activity (Gopal reddy, 1997) (Table 1). 
Table.1 Plant height, leaf area index, dry matter accumulation $(\mathrm{g}) /$ plant and protein content $(\%)$ of oat under various treatments

\begin{tabular}{|c|c|c|c|c|c|c|c|c|}
\hline \multirow[t]{2}{*}{ Characters } & \multicolumn{2}{|c|}{ Plant height (cm) } & \multicolumn{2}{|c|}{ Leaf area index } & \multicolumn{2}{|c|}{$\begin{array}{c}\text { Dry matter } \\
\text { accumulation }(\mathrm{g}) / \text { plant }\end{array}$} & \multicolumn{2}{|c|}{ Protein content (\%) } \\
\hline & 2009-10 & 2010-11 & 2009-10 & 2010-11 & 2009-10 & 2010-11 & 2009-10 & 2010-11 \\
\hline \multicolumn{9}{|l|}{ Varieties } \\
\hline Kent (V1) & 41.01 & 42.42 & 3.29 & 3.56 & 3.34 & 3.66 & 5.05 & 5.16 \\
\hline JHO 822 (V2) & 41.92 & 43.36 & 3.45 & 3.61 & 3.49 & 3.78 & 5.25 & 5.35 \\
\hline JHO 851 (V3) & 41.69 & 42.85 & 3.51 & 3.70 & 3.43 & 3.75 & 5.47 & 5.59 \\
\hline SEm \pm & 0.25 & 0.24 & 0.04 & 0.04 & 0.014 & 0.028 & 0.081 & 0.080 \\
\hline CD $(5 \%)$ & 0.72 & 0.73 & 0.11 & 0.12 & 0.039 & 0.082 & 0.23 & 0.22 \\
\hline \multicolumn{9}{|l|}{ Fertilizer Management } \\
\hline $50 \%$ of RDF & 35.78 & 36.97 & 2.72 & 2.94 & 2.59 & 2.83 & 4.67 & 4.80 \\
\hline $75 \%$ of RDF & 41.97 & 43.10 & 3.37 & 3.60 & 3.18 & 3.57 & 5.69 & 5.79 \\
\hline $100 \%$ of RDF & 46.95 & 48.15 & 3.62 & 3.79 & 3.58 & 3.79 & 6.04 & 6.15 \\
\hline $\begin{array}{l}50 \% \text { of RDF + Vermi } \\
\text { Compost }\end{array}$ & 38.28 & 39.62 & 3.29 & 3.42 & 3.35 & 3.64 & 4.48 & 4.58 \\
\hline $\begin{array}{l}50 \% \text { of RDF + } \\
\text { Azotobactor }\end{array}$ & 38.00 & 39.19 & 3.19 & 3.63 & 3.05 & 3.33 & 5.36 & 5.48 \\
\hline $\begin{array}{l}50 \% \text { of RDF + Vermi } \\
\text { Compost + Azotobactor }\end{array}$ & 42.97 & 44.29 & 3.99 & 4.19 & 4.00 & 4.33 & 5.89 & 6.01 \\
\hline $\begin{array}{l}75 \% \text { of RDF + Vermi } \\
\text { Compost }\end{array}$ & 41.16 & 43.43 & 3.11 & 3.27 & 3.54 & 3.89 & 4.20 & 4.29 \\
\hline $\begin{array}{l}75 \% \text { of RDF + } \\
\text { Azotobactor }\end{array}$ & 41.32 & 42.47 & 3.20 & 3.38 & 3.28 & 3.66 & 5.25 & 5.37 \\
\hline $\begin{array}{l}75 \% \text { of RDF + Vermi } \\
\text { Compost + Azotobactor }\end{array}$ & 47.42 & 48.66 & 4.23 & 4.38 & 4.23 & 4.53 & 5.70 & 5.83 \\
\hline SEm \pm & 0.44 & 0.43 & 0.07 & 0.07 & 0.024 & 0.049 & 0.14 & 0.13 \\
\hline CD $(5 \%)$ & 1.24 & 1.25 & 0.19 & 0.21 & 0.068 & 0.14 & 0.39 & 0.40 \\
\hline
\end{tabular}


Thus, these two organic manures in combination resulted in better growth of plant. Similar results have been reported by Gill et al., (1992). These results are in conformity with Chandrashekara et al., (2000) in maize and Amurtheshwara et al., (2015) in rice bean. Lowest leaf: stem ratio was recorded with variety $\mathrm{JHO} 822$ during both the years. The leaf: stem ratio decreased significantly with integration of fertilizers, vermin compost and bio-fertilizers than the chemical fertilizers alone from $13.02 \& 12.61$ to $6.17 \& 6.04$ during both the years respectively. The application of $75 \%$ of RDF + Vermi Compost + Azotobactor resulted in significantly lowest leaf: stem ratio during both the years. This may be due to the fact that as the increasing levels of nitrogen increased the accumulation of photosynthates towards stem as compared to the leaves, thus the proportion of stem was enhanced as compared to leaves. The crude protein is directly responsible for quality of fodder. The results on protein percentage in fodder showed the similar trend as observed in case of $\mathrm{N}$-content, because the protein content is the resultant of multiplying of $\mathrm{N}$ content. The application of $50 \%$ of $\mathrm{RDF}+$ Vermi Compost + Azotobactor proved significantly superior to all other nutrient management and noted the highest values of $5.89 \& 6.01 \%$ which was at par with $75 \%$ of RDF + Vermi Compost + Azotobactor (5.70 \& $5.83 \%)$, respectively during both the years. The combined application of Azotobactor alongwith vermicompost enhanced the green fodder and dry matter yields significantly as compared to other treatments. This may be due to the fact that Azotobator fixed higher amount of atmospheric nitrogen in soil which promoted root growth and thereby increased nutrients uptake by the crop. Azotobactor might have also increased the availability of phosphorus to plants (Ganeshe, 1996). According to Martinez Toledo et al., (1988), improvement in growth and yield due to
Azotobactor may be because of the ability of the inoculant to produce some biologically active compounds such as gibberellins and vitamins which can stimulate plant growth. Application of higher doses of nitrogen may have increased the nitrogen concentration in the plant and hence the crude protein content. More protein yield due to applied $\mathrm{N}$ levels may be explained from the fact that observed nitrogen in the form of nitrate $\left(\mathrm{NO}_{3}\right)$ is reduced to $\left(\mathrm{NH}_{3}\right)$ which is then converted to aminoacids. The proteins are formed by the fusion of the aminoacids and liberating the water molecules. Similar findings have also been made by Pandey et al., (1998).

\section{References}

Amurtheswaran, N. G., Andanigowda and Dhanapal, G. N. (2015). Effect of different organic manures on yield and economics of rice bean (Vigna abmellate Thumb). Mysore J. of Agril. Sci., 39(3): 331-334.

Chandrashekara, C. P., Harlapur, S. I., Muralikrishna, S. and Girijesh, G. K. (2000). Response of maize (Zea mays L.) to organic manures with inorganic fertilizers.

cropping system. Ph.D. Thesis, Acharya N. G. Ranga Agril. Uni., Rajendranagar, Hyderabad.

Eghball B, Ginting D, Gilley JE (2014). Residual effects of manure and compost applications on corn production and soil properties. Agron. J. 96:442-447

Gill, A.S., Manpa, D.K., Pandey, R. K. And M. Mannikar (1992). Effect of different levels of NCP on fodder yield and chemical composition of sorghum and cowpea. Indian Journal of Agricultural Res. 6(3): 185-190.

Gopalreddy, B. (1997). Soil health under integrated nutrient management in maize soybean

Hirzel, J., I. Walter, P. Undurraga, and M. 
Cartagena. (2017). Residual effects of poultry litter on silage maize (Zea mays L.) growth and soil properties derived from volcanic ash. Soil Sci. Plant Nutr. 53:480-488.

Martinez-Toledo, M.V., J. Gonzalez-Lopez, T. De la Rubia, J. Moreno and A. Ramos-ormenzana (1988). Effect of inoculation with Azotobacter chroococcum on nitrogenase activity of Zea mays roots grown in agricultural soils under aseptic and non-sterile conditions. Biol. Fertility Soils, 6: 170173.

Pandey T.D., Namdeha K.L., Saxena R.R. (1998). Crop compatibility and fertility levels in maize forage crop under bastar agro-climatic conditions. Forage Res. 24(1):57-59

Willrich, T., Jurmer, D. O. and Volk, V. V. (1974) Manure application guidelines for pacific northwest, ASAE. Am. Soc. of Agril. Engg., St. Joseph, MI. paper No. 74-4601.

\section{How to cite this article:}

Alankar Singh and Pallavi. 2019. Effect of Various Sources of Nutrients on Oats Fodder. Int.J.Curr.Microbiol.App.Sci. 8(02): 890-894. doi: https://doi.org/10.20546/ijcmas.2019.802.101 